\title{
PEMBUATAN NATA DE RICE DARI AIR CUCIAN BERAS DALAM BEBERAPA KONSENTRASI DENGAN BAKTERI Acetobacter xylinum
}

\author{
A.Suparlan Isya Syamsu, Sirajul Firdaus, Ali Imran \\ Sekolah Tinggi Ilmu Kesehatan Mega Rezky Makassar \\ Email : parlan.pance@gmail.com.
}

\begin{abstract}
The research has maked nata De rice water in several concentrations using bacteria Acetobacter xylinum. This study aims to determine the concentration of the right rice washing water, which meets the criteria of thickness, texture and color nata most optimum. This study uses three rice water concentration of $25 \%, 50 \%$ and $75 \%$, with the addition of 10\% sugar. Nata formation is based on the decomposition of sugar into a pellicle layer cellulose (nata). The cellulose layer thickness calculated using the rule and the specified quality textures and colors to use assessment of panelists. The final conclusion is that making nata of rice washing water indicates nata layer. This study showed that the addition of rice washing water at a concentration of $75 \%$ produces nata with a thickness of $2 \mathrm{~cm}$ with a good texture and color.
\end{abstract}

Keywords: Water Laundry Rice, Nata, Acetobacter xylinum.

\section{PENDAHULUAN}

Nata adalah kata yang diterjemahkan dari bahasa latin "natare" yang berarti terapung-apung, sedangkan "Encyclopedia Universal Illustrade" mendefinisikan sebagai suatu lapisan yang terbentuk pada permukaan media yang menggunakan gula (Ketaren, 1978). Produk nata banyak digunakan sebagai pencampur es krim, es buah, sirup dan sebagainya (Palungkun, 1996). Nata merupakan produk fermentasi oleh bakteri Acetobacter xylinum pada substrat yang mengandung gula. Bakteri tersebut menyukai kondisi asam dan memerlukan nitrogen stimulasi aktifitasnya. Acetobacter xylinum yang ditumbuhkan pada media dengan kadar gula tinggi seperti air kelapa, sari nenas atau sari buah lainnya akan menggunakan sebagian glukosa untuk aktifitas metabolisme dan sebagian lagi diuraikan menjadi suatu polisakarida yang dikenal dengan "exracelluler cellulose" berbentuk gel. Polisakrida inilah yang disebut nata (Djide, 2006). Apabila dilakukan pengamatan secara mikroskopik akan tampak sebagai suatu masa fibril tidak beraturan yang menyerupai benang atau kapas. Nata 
Pembuatan Nata De Rice Dari Air Cucian Beras Dalam Beberapa Konsentrasi Dengan Bakteri Acetobacter xylinum

mengandung air sekitar 98\%, mencapai ketebalan nata yang paling karbohidrat $7,27 \%$, protein $0,29 \%$, lemak $0,2 \%$, kalsium $0,012 \%$, fosfor 0,002\% dan vitamin B3 $0.017 \%$ dengan tekstur agak kenyal, padat, kokoh, putih dan transparan yang menyerupai kolang-kaling (Sutarminingsih, 2004). Produk ini tergolong makanan berkalori rendah. Namun memiliki kadar serat yang tinggi sehingga baik bagi pencernaan, dapat menjaga kelangsingan tubuh, menolong penderita diabetes dan mencegah kanker usus (Warisno, 2004).

Meskipun produk nata dibuat dari bahan baku yang dikategorikan sebagai limbah tetapi produk ini disukai konsumen. Bahkan, karena bahan baku yang digunakan adalah limbah, produk nata mempunyai nilai tambah yang tinggi serta bahan bakunya dapat diperoleh dalam jumlah besar dengan harga yang relatif murah (Suryani, 2005).

Seperti penelitian-penelitian yang telah dilakukan sebelumnya diantaranya yaitu pembuatan Nata De Banana Dari Sari Limbah Kulit Pisang Kepok Dalam Beberapa Konsentrasi Menggunakan Bakteri Acetobacter xylinum dengan tujuan untuk mengetahui konsentrasi sari limbah kulit pisang kepok yang tepat dalam

optimum. Penelitian ini menggunakan 8 konsentrasi sari limbah kulit pisang yaitu $10 \%, 20 \%, 30 \%, 40 \%, 50 \%$, $60 \%, \quad 70 \%$ dan $80 \%$, dengan penambahan gula $10 \%$. Lapisan selulosa ini dihitung ketebalannya dengan menggunakan jangka sorong dan ditentukan kualitas tekstur, warna dan rasa menggunakan penilaian dari panelis. Dan Pembuatan Nata Dari Air Rebusan Tauge (Dahri, 2004). Hal inilah yang mendasari sehingga perlunya menemukan cara Pembuatan Nata dengan menggunakan bahan dasar lain yang mudah diperoleh dan tersedia sepanjang tahun serta harganya relatif murah, selain itu untuk penganekaragaman sumber media fermentasi nata yang pada akhirnya akan memberikan nilai ekonomis yang berarti, dan dalam hal ini digunakan air cucian beras.

Makanan pokok penduduk Indonesia adalah beras. Hal ini menunjukkan hampir setiap hari rumah tangga perharinya menghasilkan atau membuang limbah yang berupa air cucian beras. Jenis limbah ini sejak dahulu hingga sekarang belum jelas bentuk dan jenis pemanfaatannya. Umumnya terbuang percuma pada selokan-selokan atau tergenang bersama air limbah lainnya 
Pembuatan Nata De Rice Dari Air Cucian Beras Dalam Beberapa Konsentrasi Dengan Bakteri Acetobacter xylinum

(Djajakusuma, 1990). Selaput beras (pada bagian permukaan butir pati pecah kulit) merupakan sumber vitamin B1 (Thiamin) yang penting dalam metabolisme tubuh serta dikenal sebagai zat anti beri. Disamping air cucian beras cukup banyak mengandung karbohidrat, protein dan mineral yang terbawa dari selaput beras ketika dicuci. Dengan demikian dimungkinkan untuk dapat dimanfaatkan sebagai media bagi mikroorganisme untuk keperluan tertentu. Salah satu diantaranya adalah untuk media yang digunakan dalam pembuatan nata (Buckle, 1987).

\section{METODE PENELITIAN}

\section{Prosedur Penelitian}

\section{Alat dan Bahan}

Alat-alat yang digunakan adalah autoklaf (Sansenyiliaogixie), blender (Miyako), jarum ose (Pyrex), Mistar (Biola), kertas pH (Universal), tabung reaksi (Pyrex), gelas erlenmeyer (Pyrex), laminary Air Flow (Mascotte), Oven (Maspion), Timbangan Kasar (Mekar), Timbangan Analitik (ACIS), Termometer (Safety), Toples (Kiramas), botol plastik (Aqua).

Bahan-bahan yang digunakan adalah air cucian beras, air suling, nanas matang 1 buah, agar, asam asetat glacial, biakan murni bakteri
Acetobacter xylinum, ekstrak khamir, glukosa, $\mathrm{K}_{2} \mathrm{HPO}_{4}, \mathrm{MgSO}_{4},\left(\mathrm{NH}_{4}\right)_{2} \mathrm{SO}_{4}$.

\section{Prosedu Kerja}

\section{Pengambilan Sampel}

Sampel yang diambil dari air cucian beras Cap Kepala yaitu pada pencucian air beras pertama, kedua, dan ketiga.

\section{Penyiapan Alat}

Alat-alat yang digunakan dicuci dengan air dan deterjen kemudian dibilas dengan air suling dan dikeringkan. Alat-alat yang terbuat dari gelas disterilkan dengan menggunakan oven pada suhu $180^{\circ} \mathrm{C}$ selama 2 jam. Sedangkan untuk alatalat yang terbuat dari logam disterilkan dengan cara dipijarkan dengan menggunakan Bunsen dan alat-alat yang terbuat dari karet dan plastic serta gelas ukur disterilkan dalam autoklaf pada suhu $121^{\circ} \mathrm{C}$ selama 15 menit.

\section{Penyiapan Mikroba}

\section{Pembuatan Medium Agar Miring}

Bahan ditimbang, kemudian dicampurkan agar, air cucian beras, glukosa, asam asetat glasial, $\mathrm{K}_{2} \mathrm{HPO}_{4}$, $\left(\mathrm{NH}_{4}\right)_{2} \mathrm{SO}_{4}, \mathrm{MgSO}_{4}$, ekstrak khamir. Setelah itu diencerkan dengan air steril kemudian dipanaskan larutan hingga bahan larut, bahan kemudian dimasukkan kedalam erlenmeyer dan ditutup dengan kapas. Setelah itu 
Pembuatan Nata De Rice Dari Air Cucian Beras Dalam Beberapa Konsentrasi Dengan Bakteri Acetobacter xylinum

disterilkan dalam autoklaf pada suhu $121^{\circ} \mathrm{C}$ selama 15 menit kemudian dimasukkan larutan kedalam tabung reaksi yang telah disterilkan dan didiamkan dalam posisi miring sampai membeku.

\section{Peremajaan biakan mikroba}

Biakan Acetobacter xylinum diremajakan dengan cara menginokulasikan pada agar miring, selanjutnya diinkubasi pada suhu $37^{\circ} \mathrm{C}$ selama $2 \times 24$ jam .

\section{Pembuatan medium starter}

Bahan ditimbang kemudian air cucian beras dipanaskan, setelah itu ditambahkan glukosa, ammonium sulfat dan ekstrak khamir lalu diaduk hingga larut kemudian dipanaskan pada suhu $100^{\circ} \mathrm{C}$ selama 15 menit, diatur $\mathrm{pH}$ 3-4 dengan menambahkan asam asetat glasial. Kemudian dituang kedalam botol starter yang telah disterilkan.

\section{Fermentasi medium starter}

Biakan Acetobacter xylinum yang telah diremajakan disuspensikan dengan air steril. Suspensi bakteri ini kemudian diinokulasikan kedalam medium starter, selanjutnya wadah ditutup secara aseptis kemudian diinkubasi selama $6 \times 24$ jam pada suhu kamar.

\section{Cara Membuat Bakteri Acetobacter xylinum (Bakteri Nata)}

Kupas nanas matang sebanyak 1 buah, kemudian dicuci hingga bersih. Setelah itu potong kecil-kecil nanas tersebut, dan dimasukkan kedalam blender (penghancur lainnya seperti parutan), Setelah dihancurkan, peras air nanas dan disaring. Setelah itu pakai ampas nanas dengan saringan, kemudian tambahkan gula pasir dan air yang telah dididihkan sebelumnya dan dibiarkan dingin. Dengan perbandingan ampas nanas : gula : air $=6: 3: 1$. Aduk campuran tersebut sampai rata, kemudian masukkan kedalam botol yang tertutup rapat dan diamkan selama 2-3 minggu sampai terbentuk lapisan putih diatas campuran tersebut. Dan simpan didalam temperatur kamar, jangan membuka tutup botolnya. Bagian yang digunakan untuk membuat nata adalah air dari campurannya tersebut yang mengandung bakteri Acetobacter xylinum.

\section{Pembuatan Nata dengan konsentrasi air cucian beras $25 \%$, $50 \%, 75 \%$}

Air cucian beras dimasukkan kedalam wadah steril sebanyak $125 \mathrm{~mL}$ (konsentrasi 25\%), $250 \mathrm{~mL}$ (konsentrasi $50 \%$ ) dan $375 \mathrm{~mL}$ (konsentrasi $75 \%$ ) lalu dididihkan kemudian tambahkan gula sebanyak 50gram. Hasil larutan ditambahkan 
Pembuatan Nata De Rice Dari Air Cucian Beras Dalam Beberapa Konsentrasi Dengan Bakteri Acetobacter xylinum

ammonium sulfat sebanyak 2,5gram kemudian diatur $\mathrm{pH}=4$ dengan penambahan asam asetat glasial. Setelah itu, didinginkan lalu ditambahkan starter sebanyak $50 \mathrm{ml}$ dan ditutup secara aseptis kemudian diinkubasi selama $14 \times 24$ jam dalam suhu kamar.

\section{Pengukuran Ketebalan}

Pengukuran ketebalan nata yang diperoleh ditentukan berdasarkan pengukuran dengan menggunakan alat mistar. Nata yang telah dipanen kemudian diukur dengan menggunakan mistar.

\section{Penentuan Tekstur}

Penentuan tekstur dari nata yang diperoleh dilakukan berdasarkan hasil penilaian dari 10 panelis. Nata yang dipanen, direndam dalam air selama 24 jam lalu dimasak untuk menghilangkan kelebihan asamnya, setelah itu ditiriskan selama 1-2 jam. Nata yang telah ditiriskan dinilai oleh masing-masing panelis berdasarkan tingkat kesukaan panelis (skala hedonik) dengan menggunakan pembanding berupa produk nata de coco yang terdapat dipasaran. Skala hedonik yang digunakan adalah sangat tidak suka (1), tidak suka (2), agak tidak suka (3), agak suka (4), suka (5), sangat suka (6) dan sangat suka sekali (7).

\section{Penetuan Warna}

Penentuan warna dari nata yang diperoleh dilakukan berdasarkan hasil penilaian dari 10 panelis. Nata yang dipanen, direndam dalam air selama 24 jam lalu dimasak untuk menghilangkan kelebihan asamnya, setelah itu ditiriskan selama 1-2 jam. Nata yang telah ditiriskan dinilai oleh masing-masing panelis berdasarkan tingkat kesukaan panelis (skala hedonik) dengan menggunakan pembanding berupa produk nata de coco yang terdapat dipasaran. Skala hedonik yang digunakan adalah sangat tidak suka (1), tidak suka (2), agak tidak suka (3), agak suka (4), suka (5), sangat suka (6) dan sangat suka sekali $(7)$

\section{HASIL PENELITIAN}

Tabel 1. Hasil Pengukuran Ketebalan Nata yang di peroleh

\begin{tabular}{cccc}
\hline \multirow{2}{*}{ Replikasi (cm) } & \multicolumn{3}{c}{ Air Cucian Beras } \\
\cline { 2 - 4 } & $\mathbf{2 5 \%}$ & $\mathbf{5 0 \%}$ & $\mathbf{7 5 \%}$ \\
\hline II & 1 & 1,3 & 1,9 \\
III & 0,8 & 0,9 & 1,4 \\
Jumlah & 0,5 & 0,7 & 2 \\
Rata-Rata & 2,3 & 2,9 & 5,3 \\
& 0,76 & 0,96 & 1,76 \\
\hline
\end{tabular}


Pembuatan Nata De Rice Dari Air Cucian Beras Dalam Beberapa Konsentrasi Dengan Bakteri Acetobacter xylinum

1. Hasil pengukuran ketebalan nata yang diperoleh yaitu pada konsentrasi $25 \%=1 \mathrm{~cm}$, konsentrasi $50 \%=1,3 \mathrm{~cm}$, dan konsentrasi $75 \%=2 \mathrm{~cm}$. Hasil selanjutnya dapat dilihat pada tabel 1.

2. Rata-rata hasil pengamatan uji organoleptik nata (tekstur) yang diperoleh yaitu pada konsentrasi $25 \%=5,33$ (suka), konsentrasi $50 \%=6,33$ (sangat suka) dan konsentrasi $75 \%=7,00$ (sangat suka sekali).

3. Rata-rata hasil pengamatan uji organoleptik nata (warna) yang diperoleh yaitu pada konsentrasi $25 \%=6,00$ (sangat suka), konsentrasi $50 \%=6,67$ (sangat suka) dan konsentrasi $75 \%=7,00$ (sangat suka sekali).

\section{PEMBAHASAN}

Penelitian ini dilakukan untuk mengetahui pengaruh penambahan konsentrasi air cucian beras dari konsentrasi $25 \%$. 50\% dan $75 \%$ terhadap tingkat ketebalan, tekstur dan warna dari nata yang dihasilkan.

Dalam penelitian ini menunjukkan air cucian beras pada konsentrasi $25 \%$, 50\% dan $75 \%$ memberikan pengaruh yang sangat nyata terhadap ketebalan nata yang dihasilkan. Sesuai dengan hasil penelitian, penambahan konsentrasi air cucian beras dan gula memberikan ketebalan nata yang tinggi, terutama pada air cucian beras konsentrasi $75 \%$.

Diamati pertumbuhannya, nata ini terus mengalami pertumbuhan dari hari kelima hingga hari keempat belas. Dengan campuran air cucian beras dan gula maka diperoleh ketebalan nata yang optimum dan dapat terbentuk dengan waktu fermentasi yaitu 14 hari. Hal ini disebabkan konsentrasi karbohidrat yang berasal dari gula, digunakan bakteri Acetobacter xylinum untuk memperoleh energi yang diperlukan bagi metabolisme sel. Selain itu, bakteri ini juga mengeluarkan enzim yang mampu menyusun (mempolimerisasi) senyawa glukosa menjadi polisakarida yang dikenal dengan selulosa ekstraseluler (nata), sedangkan air cucian beras yang ada dalam media fermentasi juga mengandung karbohidrat yang dibutuhkan dalam pembentukan kofaktor enzim yang dihasilkan oleh Acetobacter xylinum. Sehingga campuran gula dan air cucian beras merupakan konsentrasi yang optimum untuk pertumbuhan bakteri Acetobacter xylinum sehingga kegiatan metabolismenya mencapai 
Pembuatan Nata De Rice Dari Air Cucian Beras Dalam Beberapa Konsentrasi Dengan Bakteri Acetobacter xylinum

taraf paling tinggi dengan waktu fermentasi yang singkat dapat menghasilkan lapisan nata yang tebal.

Pengujian secara organoleptik juga dilakukan dengan tujuan untuk mengetahui kelayakan dari produk yang dihasilkan untuk dikonsumsi. Pengujian organoleptik terhadap nata ini dilakukan terhadap tekstur dan warna dengan menggunakan pembanding berupa produk nata de coco yang terdapat dipasaran. Kedua faktor tersebut dilihat dari tingginya skor yang diberikan oleh panelis

\section{Tekstur}

Pada perlakukan ini, nilai tertinggi yang diperoleh dari penambahan konsentrasi air cucian beras $75 \%$ dengan nilai 7,00 sedangkan nilai terendah diperoleh dengan penambahan konsentrasi cucian beras $25 \%$ dengan nilai 5,00. Hal ini menunjukkan bahwa pada penambahan konsentrasi air cucian beras $25 \%$, jumlah gula (karbohidrat) yang terdapat dalam media belum mencapai batas optimum sehingga menghasilkan produk nata yang lembut (kurang kenyal). Hal ini disebabkan jumlah air yang terikat pada lapisan nata masih tinggi dan menghasilkan konsistensi lapisan yang longgar. Sedangkan pada perlakuan penambahan air cucian beras $75 \%$ diperoleh nilai yang tinggi. Hal ini disebabkan karena dengan penambahan konsentrasi air cucian beras $75 \%$ tekstur yang diperoleh lebih kenyal.

\section{Warna}

Warna dari suatu produk berhubungan langsung dengan penampakan oleh indera penglihatan sehingga dapat mempengaruhi penerimaan konsumen terhadap produk nata tersebut. Warna nata yang diperlihatkan adalah warna putih yang merupakan ciri khas dari warna nata.

Dari hasil uji sensorik, produk nata yang dihasilkan berkisar antara sangat suka sekali $(7,00)$ pada perlakuan penambahan air cucian beras $75 \%$ hingga sangat suka $(6,00)$ pada perlakuan penambahan air cucian beras $25 \%$. Hal ini disebabkan karena konsentrasi 25\% mengandung jumlah air cucian beras yang sedikit, jadi dalam hal ini warna nata dipengaruhi oleh endapan air cucian beras yang berbentuk pada dasar media.

Dari hasil pengamatan dari ketiga parameter yang digunakan diperoleh bahwa hasil penambahan air cucian beras yang paling baik adalah $75 \%$. Hal ini disebabkan karena hasil pada konsentrasi tersebut mempunyai 
Pembuatan Nata De Rice Dari Air Cucian Beras Dalam Beberapa Konsentrasi Dengan Bakteri Acetobacter xylinum

ketebalan yang tertinggi dengan

Produksi Enzim. Balitbang tekstur dan warna yang lebih baik.

\section{KESIMPULAN}

Berdasarkan hasil penelitian, maka dapat disimpulkan bahwa ketebalan nata yang paling optimum yaitu $2 \mathrm{~cm}$ yang diperoleh dengan penambahan konsentrasi air cucian beras $75 \%$ dengan tekstur dan warna yang baik.

\section{DAFTAR PUSTAKA}

Buckle, dkk.1987. Food Science. Australian Vice Canchelors Commite. Brisbane,208-210

Dahri,B. 2004. Pembuatan Nata Dari Media Air Tanah Dengan Penambahan Air Rebusan Tauge Dalam Beberapa Konsentrasi. Skripsi. Fakultas MIPA. Makassar,1

Djajakusuma. 1990. Pemanfaatan Limbah Cair Cucian Beras Untuk Mikrobiologi Puslitbang Biologi. LIPI Bogor. Bandung,2,3

Djide, M.N. 2006. Penuntun Praktikum Bioteknologi Farmasi. Universitas Hasanuddin. Makassar.50

Ketaren, S. 1978. Daya Guna Kelapa. Departemen Teknologi Hasil Pertanian. Fakultas Pertanian. Bogor.2

Palungkun, R. 1996. Aneka Produk Olahan Kelapa. Jakarta;Penabar swadaya.2

Suryani, A. 2005. Membuat Aneka Nata. Jakarta;Penebar Swadaya.3,4

Sutarminingsih, L.C. 2004. Peluang Usaha Nata De Coco. Yogyakarta; konisius.22

Warisno. 2004. Mudah dan Praktis Membuat Nata De Coco. Jakarta;Agromedia pustaka.2 